\title{
Effect of Different Amounts of Biochar on Meadow Soil Characteristics and Maize Yields Over Three Years
}

\begin{abstract}
Zhihui Wang, ${ }^{\mathrm{a}}$ Chunshuang Tang, ${ }^{\mathrm{b}}$ Hongyi Wang, ${ }^{\mathrm{a}}$ Changjiang Zhao, ${ }^{\mathrm{a}}$ Dawei Yin, ${ }^{\mathrm{a}}$ Ye Yuan, ${ }^{\mathrm{a}, \mathrm{c}}$ Kejun Yang, ${ }^{\mathrm{a}}$ and Zuotong $\mathrm{Li}^{\mathrm{a}}{ }^{\mathrm{a} *}$

To evaluate the effect of biochar on soil characteristics and maize yields in meadow soil, a three-year field experiment was performed using different amounts of biochar $(0,10,20,40$, and $80 \mathrm{t} / \mathrm{ha})$. The soil $\mathrm{pH}$ decreased over time when biochar was applied to weakly basic soil. Single biochar applications increased the organic carbon, total nitrogen, available $\mathrm{K}$, and cation exchange capacity for three continuous years, in proportion to the amount of biochar applied. However, as time progressed, the soil organic carbon, total nitrogen, available $\mathrm{K}$, and cation exchange capacity began to decrease. The biochar stimulated the availability of soil phosphorus in the meadow soil and stably increased the available $\mathrm{P}$ content in the soil for three years. For maize, the biochar application decreased the occurrence of barren ear tips and increased the ear length, grain number per row, 100-kernel weight, and yield. When the single applications of biochar were greater than $40 \mathrm{t} / \mathrm{ha}$, the soil characteristics showed continuous improvements and the maize yields stably increased for three years.
\end{abstract}

Keywords: Biochar; Maize; Soil nutrients; Maize yield

Contact information: a: College of Agronomy, Heilongjiang Bayi Agricultural University and Heilongjiang Engineering Technology Research Center for Crop Straw Utilization, Key Laboratory of Modern Agricultural Cultivation and Crop Germplasm Improvement of Heilongjiang Province, Daqing 163319, Heilongjiang, China; $b$ : Institute of Crop Research, Heilongjiang Academy of Land Reclamation Sciences, Jiamusi 154007, Heilongjiang, China; c: Mudanjiang Tobacco Science Research Institute, Harbin 150076, Heilongjiang, China; *Corresponding author: lxg64019@163.com

\section{INTRODUCTION}

Heilongjiang province is a major agricultural region in China with large maize cultivation areas, although their yields are generally low. In recent years, frequent spring droughts, severe soil compaction, plow layer thickening, and poor permeability have severely limited the sustainable development of agriculture in this region. As food demand continues to increase, it is imperative to ensure food security by improving the soil structure, regulating soil fertility, and increasing soil nutrient utilization, to develop an efficient farmland ecological environment. The province is also rich in straw resources, with an annual straw yield of 80 to 90 million tons. Approximately $30 \%$ of the straw is incinerated as waste. This not only wastes resources but also affects the ecosystem balance in farmlands. It reduces soil input, decreases farmland fertility, and increases greenhouse gas emissions, which cause severe smog. Therefore, it is important to develop methods for utilizing these ample straw resources, along with eco-friendly and energy-saving technologies that reduce emissions, allow for low-carbon recycling, and ensure the sustainable development of agriculture. 
In recent years, biochar has attracted attention across the agricultural sector. The term 'biochar' refers to stable, high-carbon products from agricultural waste (such as straw) that have undergone high-temperature pyrolysis in anoxic or hypoxic conditions (Lehmann et al. 2006). Biochar possesses a highly aromatic structure with a high content of carboxylic esters. Moreover, it is porous, with a large specific surface area, strong adsorption capabilities, substantial amounts of surface negative charges, and high charge density (Lehmann et al. 2011; Yin et al. 2014).

Biochar can be used as an ideal soil conditioner, as its application can decrease bulk density and nutrient leaching and increase soil porosity, aeration, water holding capacity, soil organic matter content, and cation exchange capacity (CEC); it can also increase the adsorption of nitrogen, phosphorus, and potassium, as well as fertilizer utilization rates (Glaser et al. 2002; Oguntunde et al. 2008; Lehmann and Joseph 2009; Bruun et al. 2014; Rehrah et al. 2016). Meanwhile, biochar can promote crop growth, increasing the amount of available biomass, crop yields, and overall quality (Mohammadi 2012; Liang et al. 2014; Jin et al. 2015).

Previous studies of biochar on soil amelioration have focused on acidic soils (Novak et al. 2009; Hong 2018; Lin 2018), and few studies have focused on semi-arid saline-alkali soils. Most of the previous research has also focused on the effects of biochar during the growing season (Zhang et al. 2010; Akhtar et al. 2015), with few studies showing that a single application of biochar can have consistent beneficial effects for multiple years after its application.

In this study, a 3-year field experiment was performed to examine the effects on soil physiochemical properties and maize yields, when different amounts of straw biochar in single application treatments, were applied to semi-arid meadow soil in the western Heilongjiang province of China. The aim was to determine a workable quantity-effect relationship for biochar in maize production, while simultaneously investigating the effective duration of the biochar. The results from this investigation will improve the ability to sustainably utilize semi-arid agricultural soils.

\section{EXPERIMENTAL}

\section{Materials and Design}

The study was conducted from 2014 to 2016 at the experimental base of Heilongjiang Bayi Agricultural University in western Heilongjiang province (Daqing, China). The maize variety used was Zhengdan 958 . The 0 to $20 \mathrm{~cm}$ plow layer of the soil used had the following characteristics: a $\mathrm{pH}$ of 7.84, an organic matter content of 27.59 $\mathrm{g} / \mathrm{kg}$, a total nitrogen content of $1.72 \mathrm{~g} / \mathrm{kg}$, an alkaline hydrolysable nitrogen content of 120 $\mathrm{mg} / \mathrm{kg}$ ( $1 \mathrm{~mol} / \mathrm{L} \mathrm{NaOH}$ hydrolysis-titration), an available $\mathrm{P}$ content of $12.25 \mathrm{mg} / \mathrm{kg}$, and an available $\mathrm{K}$ content of $132.93 \mathrm{mg} / \mathrm{kg}$. The experimental biochar material was provided by Liaoning Jinhefu Agriculture Development Co. (Anshan, China). The raw material for pyrolysis was maize straw (Liaodan). The pyrolysis conditions were $450{ }^{\circ} \mathrm{C}$ for $2 \mathrm{~h}$, and the detailed charring method can be found in the Chinese patent CN 102092709 B (Chen 2012). The basic physiochemical characteristics of the biochar were as follows: a $\mathrm{pH}$ of 7.94 , an organic carbon content of $440.6 \mathrm{~g} / \mathrm{kg}$, a total nitrogen content of $15.34 \mathrm{~g} / \mathrm{kg}$, a total phosphorous content of $7.81 \mathrm{~g} / \mathrm{kg}$, and a total potassium content of $16.82 \mathrm{~g} / \mathrm{kg}$. 
A randomized plot design was employed for the experiment, in which five treatments were set up. These treatments included applying biochar at $0 \mathrm{t} / \mathrm{ha}(\mathrm{CK}), 10 \mathrm{t} / \mathrm{ha}$ (C10), 20 t/ha (C20), 40 t/ha (C40), and 80 t/ha (C80). Each treatment was completed in triplicate and there were 15 treatments in total. Each plot had six rows, $15-\mathrm{m}$ in length. The area of each plot was $58.5 \mathrm{~m}^{2}$. The cultivation method employed was $0.65-\mathrm{m}$ uniform ridge cultivation. The cultivation density was 75,000 plants $/ \mathrm{hm}^{2}$. Other field management measures were performed based on the measures for high-yielding maize-cultivated fields.

In 2014, all the biochar treatments were applied once by broadcasting on the surface of the soil before the seeds were sown. After manual plowing, a rotary tiller was used for uniform mixing of the soil from 0 to $20 \mathrm{~cm}$ depths. Each year, the same amount of fertilizers

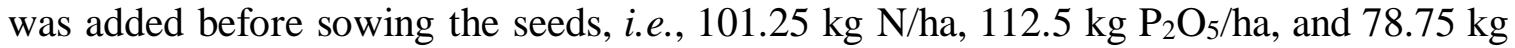
$\mathrm{K}_{2} \mathrm{O} / \mathrm{ha}$, and another $67.5 \mathrm{~kg} \mathrm{~N} / \mathrm{ha}$ was added as topdressing fertilizer when the plants had twelve expanded leaves. Urea (Jingbohu/N 46\%, Heilongjiang Beifeng Agricultural Production Means Group Co., Ltd., Harbin, China), diammonium phosphate (Fengbeiling/ $\mathrm{P}_{2} \mathrm{O}_{5} 46 \%$, Heilongjiang Beifeng Agricultural Production Means Group Co., Ltd., Harbin, China), and potassium sulfate (Lesuoshi/ $\mathrm{K}_{2} \mathrm{O} 50 \%$, Heilongjiang Beifeng Agricultural Production Means Group Co., Ltd., Harbin, China).

\section{Sample collection and measurement}

From 2014 to 2016, soil samples were collected during the seedling, jointing, tasseling, wax-ripening, and full-ripening stages of the maize plants. Topsoil samples (0$20 \mathrm{~cm}$ depth) were collected from each treatment. Five soil cores were collected using a 3$\mathrm{cm}$ diameter auger from each treatment and mixing the material into one composite sample. Soil samples were sieved through a 2-mm mesh sieve to remove roots and small rocks. The soil was air-dried in cloth bags before analysis. The soil organic carbon was quantified using the potassium dichromate volumetric method. For total nitrogen, $\mathrm{H}_{2} \mathrm{SO}_{4}$ was used as an accelerator for digestion, and then the Kjeldahl analytic method was used. Soil available $\mathrm{P}$ was extracted with $0.5 \mathrm{M}$ sodium bicarbonate and analyzed using the molybdenum blue-ascorbic acid method. Soil available K was quantified using $1 \mathrm{~mol} / \mathrm{L}$ of ammonium acetate extraction-flame photometry. The cation exchange capacity was determined via $1 \mathrm{~mol} / \mathrm{L} \mathrm{NaOAc}$ extraction followed by flame photometry (Bao 2000). To determine the yield, maize ears from each treatment group were harvested by hand from each plot at crop maturity at the end of September from 2014 to 2016. The ear length, kernel number per row, and 100-kernel weight were measured from 20 representative maize ears. The grain water content was determined, followed by the yield per hectare.

\section{Data analysis}

The data were summarized as means and standard deviations (SD) of the means using Excel 2013 software (Microsoft, Redmond, WA, USA). A one-way analysis of variance (ANOVA) was performed to determine the statistical significance $(\mathrm{p}<0.05 ; \mathrm{n}=$ 3 ) of the treatment effects using SPSS 21.0 software (IBM, Armonk, NY, USA). Duncan's new multiple range test was used for significance analysis. When considering the differences between years, a two-way analysis of variance was used with the different biochar treatments and the sampling years as the two fixed factors. GraphPad Prism 7 software (GraphPad Software, San Diego, CA, USA) was used to plot the graphs. 


\section{RESULTS AND DISCUSSION}

\section{Effects of Different Biochar Application Amounts on Meadow Soil Organic Carbon}

As shown in Table 1, the biochar significantly affected the soil organic carbon content during the different stages of maize growth $(\mathrm{p}<0.01)$. Compared with the CK treatment, the $\mathrm{C} 80$ treatment significantly increased the 3-year soil organic carbon content in various stages; the $\mathrm{C} 40$ treatment significantly increased the soil organic carbon content. The $\mathrm{C} 20$ and C10 treatments resulted in varying degrees of increase in the soil organic carbon content, compared with the CK treatment. Therefore, the application of biochar could increase soil organic carbon content proportional to the amount of biochar applied. In 2014, the initial biochar applications were made, and the soil organic carbon content increased the most, and then gradually decreased over time. (Table 2).

Table 1. Effects of Different Application Amounts of Biochar on Soil Organic Carbon from 2014 to 2016

\begin{tabular}{|c|c|c|c|c|c|c|}
\hline \multirow[t]{2}{*}{ Year } & \multirow[t]{2}{*}{ Treatment } & \multicolumn{5}{|c|}{ Soil Organic Carbon (SOC; g/kg) } \\
\hline & & $\begin{array}{l}\text { Seedling } \\
\text { Stage }\end{array}$ & $\begin{array}{l}\text { Jointing } \\
\text { Stage }\end{array}$ & $\begin{array}{l}\text { Tasseling } \\
\text { Stage }\end{array}$ & $\begin{array}{l}\text { Wax-ripening } \\
\text { Stage }\end{array}$ & $\begin{array}{l}\text { Full-ripening } \\
\text { Stage }\end{array}$ \\
\hline \multirow[t]{5}{*}{2014} & CK & $\begin{array}{c}15.52 \pm \\
0.21^{\mathrm{d}}\end{array}$ & $\begin{array}{c}15.80 \pm \\
0.63^{d}\end{array}$ & $18.69 \pm 0.73^{b}$ & $17.24 \pm 0.15^{c}$ & $16.24 \pm 0.14^{b}$ \\
\hline & C10 & $\begin{array}{c}16.65 \pm \\
0.35^{\mathrm{cd}}\end{array}$ & $\begin{array}{c}17.62 \pm \\
1.03^{\mathrm{c}}\end{array}$ & $19.78 \pm 2.70^{b}$ & $19.01 \pm 1.61^{b c}$ & $16.02 \pm 0.90^{b}$ \\
\hline & $\mathrm{C} 20$ & $\begin{array}{c}18.20 \pm \\
0.09^{c}\end{array}$ & $\begin{array}{c}19.52 \pm \\
0.19^{\mathrm{b}}\end{array}$ & $20.98 \pm 0.33^{b}$ & $18.46 \pm 2.79^{b c}$ & $18.60 \pm 2.31^{a}$ \\
\hline & C40 & $\begin{array}{c}22.16 \pm \\
1.02^{b}\end{array}$ & $\begin{array}{l}21.04 \pm \\
0.21^{\mathrm{a}}\end{array}$ & $20.46 \pm 2.07^{b}$ & $22.77 \pm 3.87^{a b}$ & $19.88 \pm 1.16^{a}$ \\
\hline & $\mathrm{C} 80$ & $\begin{array}{c}24.74 \pm \\
2.47^{a}\end{array}$ & $\begin{array}{c}21.65 \pm \\
0.63^{\mathrm{a}}\end{array}$ & $24.74 \pm 0.36^{a}$ & $24.54 \pm 2.59^{a}$ & $20.70 \pm 0.12^{a}$ \\
\hline \multirow[t]{5}{*}{2015} & $\mathrm{CK}$ & $\begin{array}{l}13.59 \pm \\
0.19^{\mathrm{e}}\end{array}$ & $\begin{array}{c}15.12 \pm \\
0.72^{\mathrm{d}}\end{array}$ & $16.22 \pm 0.19^{c}$ & $15.55 \pm 0.28^{c}$ & $14.66 \pm 0.52^{c}$ \\
\hline & C10 & $\begin{array}{c}15.06 \pm \\
0.43^{d}\end{array}$ & $\begin{array}{c}15.57 \pm \\
0.77^{d}\end{array}$ & $15.72 \pm 1.41^{\mathrm{c}}$ & $16.71 \pm 1.57^{c}$ & $15.86 \pm 0.49^{b c}$ \\
\hline & C20 & $\begin{array}{c}16.90 \pm \\
0.12^{\mathrm{c}}\end{array}$ & $\begin{array}{c}17.60 \pm \\
0.30^{c}\end{array}$ & $19.17 \pm 0.61^{b}$ & $15.85 \pm 0.30^{c}$ & $15.65 \pm 0.13^{b c}$ \\
\hline & C40 & $\begin{array}{c}20.43 \pm \\
0.48^{b}\end{array}$ & $\begin{array}{c}19.56 \pm \\
0.90^{\mathrm{b}}\end{array}$ & $\begin{array}{l}17.09 \pm \\
0.65^{\mathrm{bc}}\end{array}$ & $21.92 \pm 1.30^{b}$ & $17.00 \pm 0.79^{b}$ \\
\hline & $\mathrm{C} 80$ & $\begin{array}{c}24.60 \pm \\
0.50^{\mathrm{a}}\end{array}$ & $\begin{array}{c}36.76 \pm \\
0.44^{\mathrm{a}}\end{array}$ & $27.67 \pm 2.45^{a}$ & $26.78 \pm 0.61^{a}$ & $23.49 \pm 1.30^{a}$ \\
\hline \multirow[t]{5}{*}{2016} & CK & $\begin{array}{c}13.49 \pm \\
0.30^{d}\end{array}$ & $\begin{array}{c}13.57 \pm \\
0.44^{\mathrm{c}}\end{array}$ & $15.04 \pm 2.00^{b}$ & $14.07 \pm 0.51^{d}$ & $14.68 \pm 1.79^{b}$ \\
\hline & C10 & $\begin{array}{c}16.21 \pm \\
0.42^{c}\end{array}$ & $\begin{array}{c}20.64 \pm \\
0.71^{\mathrm{a}} \\
\end{array}$ & $15.26 \pm 0.76^{b}$ & $15.35 \pm 0.37^{c}$ & $15.24 \pm 0.77^{b}$ \\
\hline & $\mathrm{C} 20$ & $\begin{array}{c}16.83 \pm \\
0.18^{\mathrm{c}}\end{array}$ & $\begin{array}{c}14.95 \pm \\
0.77^{\mathrm{b}}\end{array}$ & $15.66 \pm 0.96^{b}$ & $16.63 \pm 0.17^{b}$ & $15.55 \pm 0.61^{b}$ \\
\hline & $\mathrm{C} 40$ & $\begin{array}{c}19.39 \pm \\
0.61^{\mathrm{b}}\end{array}$ & $\begin{array}{c}15.96 \pm \\
0.90^{\mathrm{b}}\end{array}$ & $21.14 \pm 0.79^{a}$ & $16.89 \pm 0.64^{b}$ & $18.08 \pm 0.34^{a}$ \\
\hline & C80 & $\begin{array}{c}20.12 \pm \\
0.36^{a}\end{array}$ & $\begin{array}{c}21.42 \pm \\
0.80^{\mathrm{a}}\end{array}$ & $19.66 \pm 0.77^{a}$ & $20.80 \pm 0.89^{a}$ & $19.74 \pm 0.71^{a}$ \\
\hline
\end{tabular}

Wang et al. (2019). "Biochar effects on soil \& maize," BioResources 14(2), 4194-4209. 
Table 2. Two-way Analysis of Variance of Soil Properties by Biochar and Years

\begin{tabular}{|c|c|c|c|c|c|c|}
\hline $\begin{array}{l}\text { Source of } \\
\text { variation }\end{array}$ & SOC & $\mathrm{TN}$ & AP & AK & $\mathrm{pH}$ & CEC \\
\hline Year & $* * *$ & $* \star *$ & $\mathrm{~ns}$ & $* * *$ & $* \star *$ & $* * \star$ \\
\hline Biochar & $\star \star \star *$ & $\star * *$ & $\star \star * *$ & $* * *$ & * & $\star * * *$ \\
\hline
\end{tabular}

\section{Effects of Different Amounts of Biochar on Meadow Soil Total Nitrogen}

As shown in Table 3, the biochar significantly affected the soil total nitrogen content during the different growth stages of the maize (Table 2). The C40-, C20-, and $\mathrm{C} 10$-treated soils slightly increased soil total nitrogen compared with the CK treatment, but these differences were not significant. Compared with the CK treatment, the C80 treatment significantly increased the soil total nitrogen during the different stages within the 3 -year period. This shows that the application of biochar could increase soil total nitrogen content. Additionally, as the amount of biochar applied increased, soil total nitrogen content also increased; however, it also gradually decreased as time progressed.

Table 3. Effects of Different Application Amounts of Biochar on Meadow Soil Total Nitrogen from 2014 to 2016

\begin{tabular}{|c|c|c|c|c|c|c|}
\hline \multirow[t]{2}{*}{ Year } & \multirow[t]{2}{*}{ Treatment } & \multicolumn{5}{|c|}{ Soil Total Nitrogen $(\mathrm{g} / \mathrm{kg})$} \\
\hline & & $\begin{array}{l}\text { Seedling } \\
\text { Stage }\end{array}$ & $\begin{array}{l}\text { Jointing } \\
\text { Stage }\end{array}$ & $\begin{array}{l}\text { Tasseling } \\
\text { Stage }\end{array}$ & $\begin{array}{l}\text { Wax- } \\
\text { ripening } \\
\text { Stage }\end{array}$ & $\begin{array}{l}\text { Full-ripening } \\
\text { Stage }\end{array}$ \\
\hline \multirow[t]{5}{*}{2014} & CK & $1.29 \pm 0.07^{b}$ & $1.36 \pm 0.02^{c}$ & $1.38 \pm 0.02^{\mathrm{c}}$ & $1.37 \pm 0.01^{\mathrm{c}}$ & $1.31 \pm 0.01^{d}$ \\
\hline & C10 & $1.37 \pm 0.02^{b}$ & $1.39 \pm 0.02^{c}$ & $1.38 \pm 0.04^{c}$ & $1.35 \pm 0.01^{c}$ & $1.32 \pm 0.04^{d}$ \\
\hline & C20 & $1.43 \pm 0.01^{b}$ & $1.40 \pm 0.02^{c}$ & $1.42 \pm 0.03^{c}$ & $1.42 \pm 0.01^{b}$ & $1.40 \pm 0.02^{c}$ \\
\hline & C40 & $1.47 \pm 0.20^{b}$ & $1.73 \pm 0.07^{b}$ & $1.70 \pm 0.02^{b}$ & $1.68 \pm 0.02^{\mathrm{a}}$ & $1.49 \pm 0.02^{b}$ \\
\hline & $\mathrm{C} 80$ & $1.82 \pm 0.02^{\mathrm{a}}$ & $1.95 \pm 0.02^{\mathrm{a}}$ & $1.92 \pm 0.07^{a}$ & $1.71 \pm 0.05^{\mathrm{a}}$ & $1.59 \pm 0.04^{\mathrm{a}}$ \\
\hline \multirow[t]{5}{*}{2015} & $\mathrm{CK}$ & $1.30 \pm 0.01^{\mathrm{c}}$ & $1.37 \pm 0.08^{\mathrm{c}}$ & $1.39 \pm 0.04^{b}$ & $1.33 \pm 0.02^{\mathrm{c}}$ & $1.36 \pm 0.03^{\mathrm{c}}$ \\
\hline & C10 & $1.30 \pm 0.02^{\mathrm{c}}$ & $1.40 \pm 0.03^{c}$ & $1.38 \pm 0.02^{b}$ & $1.39 \pm 0.02^{\mathrm{c}}$ & $\begin{array}{l}1.44 \pm \\
0.07 \mathrm{bc}\end{array}$ \\
\hline & $\mathrm{C} 20$ & $1.35 \pm 0.09^{c}$ & $1.45 \pm 0.02^{\mathrm{c}}$ & $1.40 \pm 0.05^{b}$ & $1.38 \pm 0.05^{c}$ & $\begin{array}{l}1.46 \pm \\
0.08^{\mathrm{bc}}\end{array}$ \\
\hline & $\mathrm{C} 40$ & $1.55 \pm 0.03^{b}$ & $1.60 \pm 0.05^{b}$ & $1.70 \pm 0.02^{\mathrm{a}}$ & $1.61 \pm 0.08^{b}$ & $1.49 \pm 0.02^{b}$ \\
\hline & $\mathrm{C} 80$ & $1.74 \pm 0.09^{a}$ & $1.91 \pm 0.06^{a}$ & $1.73 \pm 0.07^{a}$ & $1.70 \pm 0.03^{\mathrm{a}}$ & $1.72 \pm 0.04^{\mathrm{a}}$ \\
\hline \multirow[t]{5}{*}{2016} & CK & $1.26 \pm 0.02^{\mathrm{c}}$ & $1.30 \pm 0.02^{b}$ & $1.29 \pm 0.01^{\mathrm{c}}$ & $1.34 \pm 0.02^{\mathrm{c}}$ & $1.31 \pm 0.03^{\mathrm{c}}$ \\
\hline & C10 & $1.34 \pm 0.01^{b}$ & $1.33 \pm 0.02^{b}$ & $1.34 \pm 0.01^{\mathrm{c}}$ & $1.33 \pm 0.03^{c}$ & $1.35 \pm 0.05^{c}$ \\
\hline & C20 & $\begin{array}{l}1.30 \pm \\
0.04^{\mathrm{bc}}\end{array}$ & $1.35 \pm 0.04^{b}$ & $1.34 \pm 0.05^{c}$ & $1.37 \pm 0.03^{c}$ & $1.34 \pm 0.01^{c}$ \\
\hline & C40 & $1.50 \pm 0.04^{a}$ & $1.56 \pm 0.04^{a}$ & $1.46 \pm 0.02^{b}$ & $1.45 \pm 0.02^{b}$ & $1.42 \pm 0.02^{b}$ \\
\hline & C80 & $1.49 \pm 0.01^{\mathrm{a}}$ & $1.52 \pm 0.02^{\mathrm{a}}$ & $1.53 \pm 0.05^{\mathrm{a}}$ & $1.52 \pm 0.03^{\mathrm{a}}$ & $1.50 \pm 0.01^{\mathrm{a}}$ \\
\hline
\end{tabular}

Different letters after values in the same column indicate that the inter-treatment differences were significant $(p<0.05)$ 


\section{Effects of Different Amounts of Biochar on Meadow Soil C/N}

As shown in Table 4, except for the tasseling, wax-ripening, and full-ripening stages in 2014, which did not have any significant differences, the other stages in the other years all showed significant differences in soil $\mathrm{C} / \mathrm{N}$. In particular, the soil $\mathrm{C} / \mathrm{N}$ values for the different developmental stages of 2015 were highly significant. The mean $\mathrm{C} / \mathrm{N}$ values of soil with biochar applied in 2014, 2015, and 2016 were 13.2, 12.9, and 12.5, respectively, which were greater than those for the untreated soil in the corresponding years by 6.47 , 16.85 , and $15.21 \%$, respectively. This showed that the biochar application promoted soil $\mathrm{C} / \mathrm{N}$, but to varying degrees.

Table 4. Effects of Different Application Amounts of Biochar on Meadow Soil C/N from 2014 to 2016

\begin{tabular}{|c|c|c|c|c|c|c|}
\hline \multirow[t]{2}{*}{ Year } & \multicolumn{6}{|c|}{$p$-value } \\
\hline & Baseline & $\begin{array}{l}\text { Seedling } \\
\text { Stage }\end{array}$ & $\begin{array}{l}\text { Jointing } \\
\text { Stage }\end{array}$ & $\begin{array}{l}\text { Tasseling } \\
\text { Stage }\end{array}$ & $\begin{array}{l}\text { Wax- } \\
\text { ripening } \\
\text { Stage }\end{array}$ & $\begin{array}{c}\text { Full- } \\
\text { ripening } \\
\text { Stage }\end{array}$ \\
\hline 2014 & & $0.032^{*}$ & $0.001^{\star *}$ & $0.0711^{\text {ns }}$ & $0.6790^{\text {ns }}$ & $0.5040^{\text {ns }}$ \\
\hline 2015 & $<0.0001^{* * *}$ & $0.0002^{\star \star \star}$ & $<0.0001^{* \star *}$ & $0.0001^{* * *}$ & $0.0008^{\star \star \star}$ & $0.0004^{* \star \star}$ \\
\hline 2016 & $0.0197^{\star}$ & $<0.0001^{\star \star *}$ & $<0.0001^{\star \star \star}$ & $0.0120^{*}$ & $<0.0001^{\star \star \star}$ & $0.0140^{*}$ \\
\hline
\end{tabular}

\section{Effects of Different Amounts of Biochar on Meadow Soil available P and available $\mathrm{K}$}

As shown in Figs. 1 to 3, the biochar application increased soil available $\mathrm{P}$ content during the different growth stages. The $\mathrm{C} 80$ and $\mathrm{C} 40$ treatments significantly increased the soil available $\mathrm{P}$ content, and this effect was maintained for the 3-year period. As shown in Figs. 4 to 6, as the amount of biochar applied increased, the soil available $\mathrm{K}$ content also increased. In 2014, the soil available K content during various stages under the C80, C40, $\mathrm{C} 20$, and $\mathrm{C} 10$ treatments were all significantly greater than that under the $\mathrm{CK}$ treatments. In 2015, the soil available $\mathrm{K}$ content during the various stages under the C80, C40, and C20 treatments were all significantly greater than that under the CK treatment.

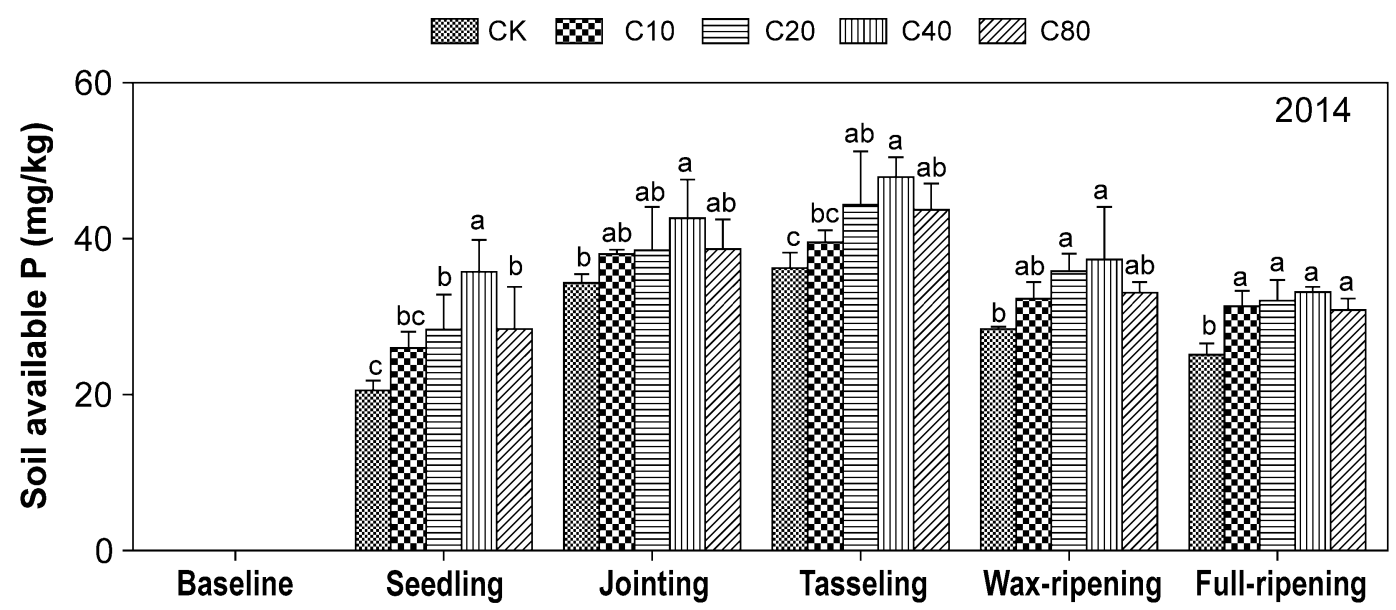

Fig. 1. Effects of different biochar treatments on meadow soil available $P$ in 2014 


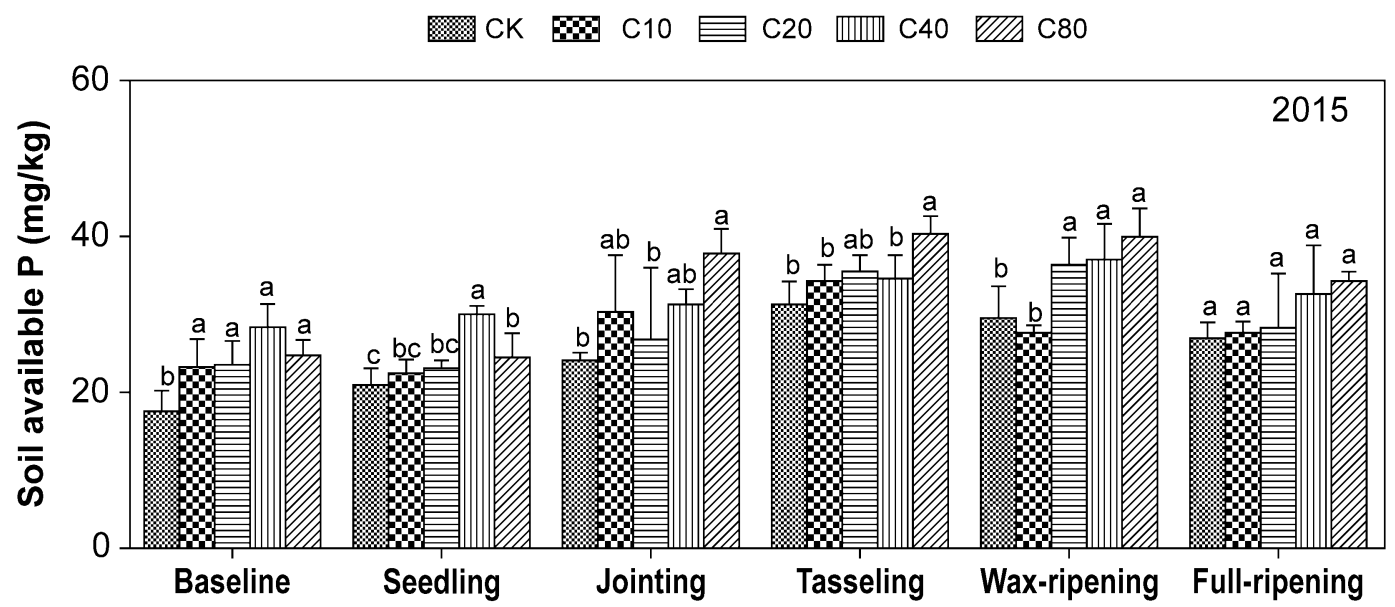

Fig. 2. Effects of different biochar treatments on meadow soil available $P$ in 2015

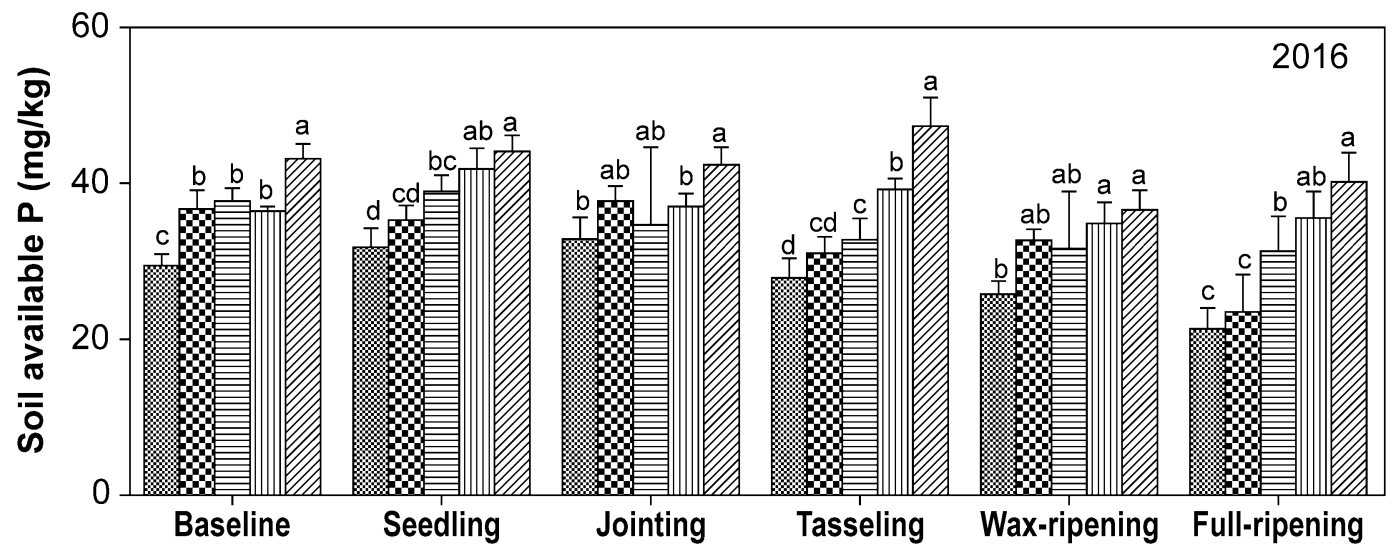

Fig. 3. Effects of different biochar treatments on meadow soil available $P$ in 2016

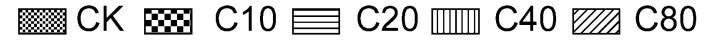

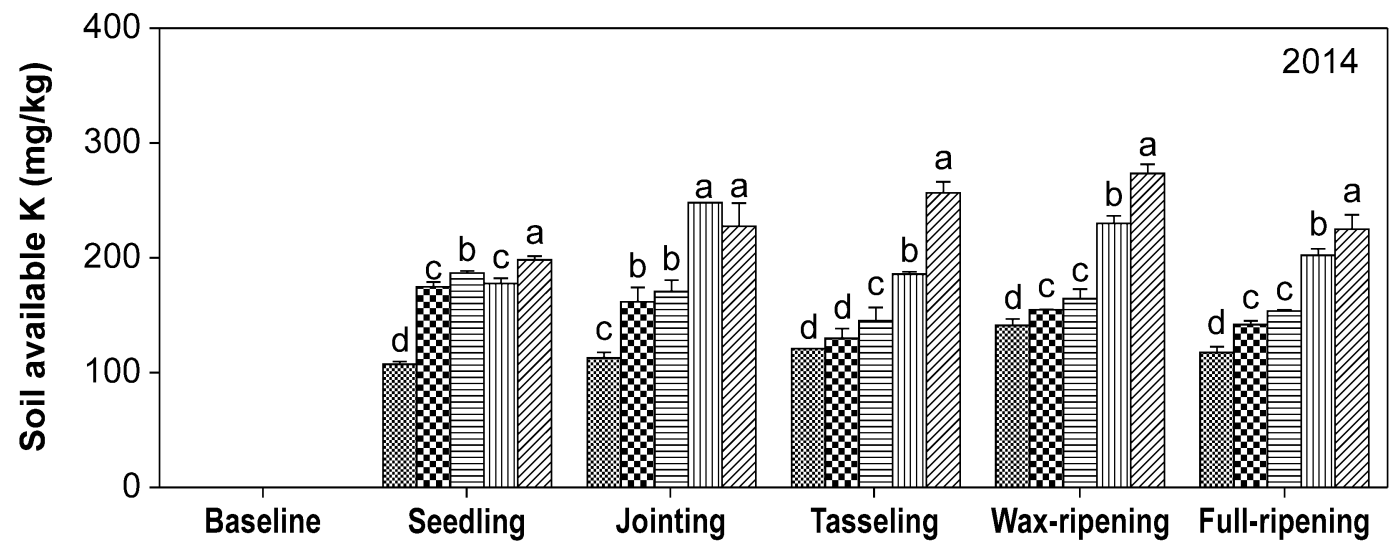

Fig. 4. Effects of different biochar treatments on meadow soil available K in 2014

In 2016, only the C80 and C40 treatments significantly promoted soil available $\mathrm{K}$ during the different growth stages when compared with the CK treatment. A two-way ANOVA found that the year had significant effects on soil available K content (Table 2). The soil potassium content in soils during the full-ripening stage of maize growth decreased as time progressed over the 3 years. 


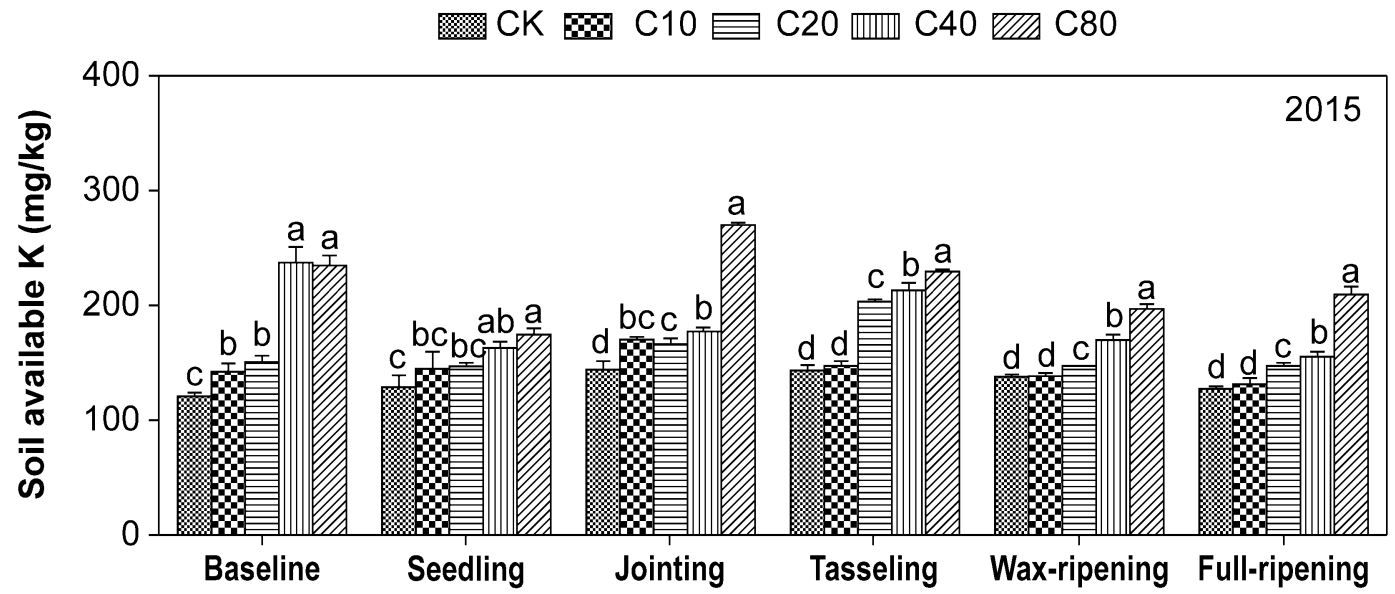

Fig. 5. Effects of different biochar treatments on meadow soil available $\mathrm{K}$ in 2015

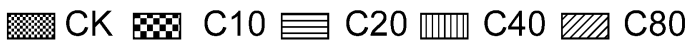

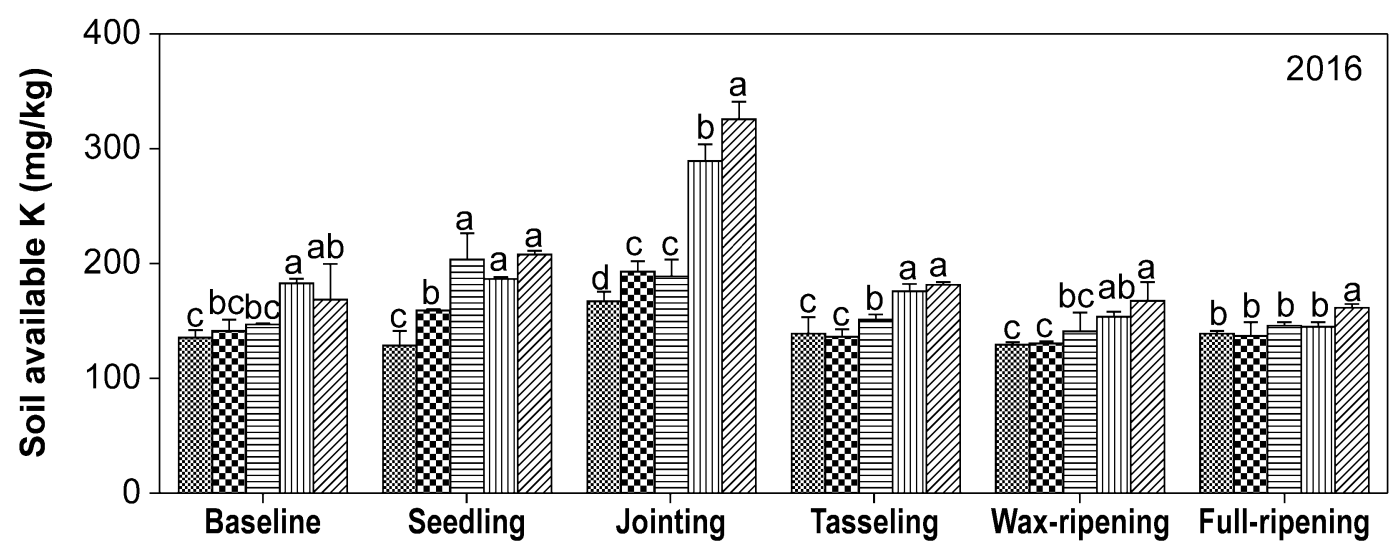

Fig. 6. Effects of different biochar treatments on meadow soil available $\mathrm{K}$ in 2016

\section{Effects of Different Amounts of Biochar on Meadow Soil pH}

As shown in Fig. 7, the effects of different application amounts of biochar on soil $\mathrm{pH}$ were as follows: The different biochar treatments applied in 2014 significantly increased soil $\mathrm{pH}$.

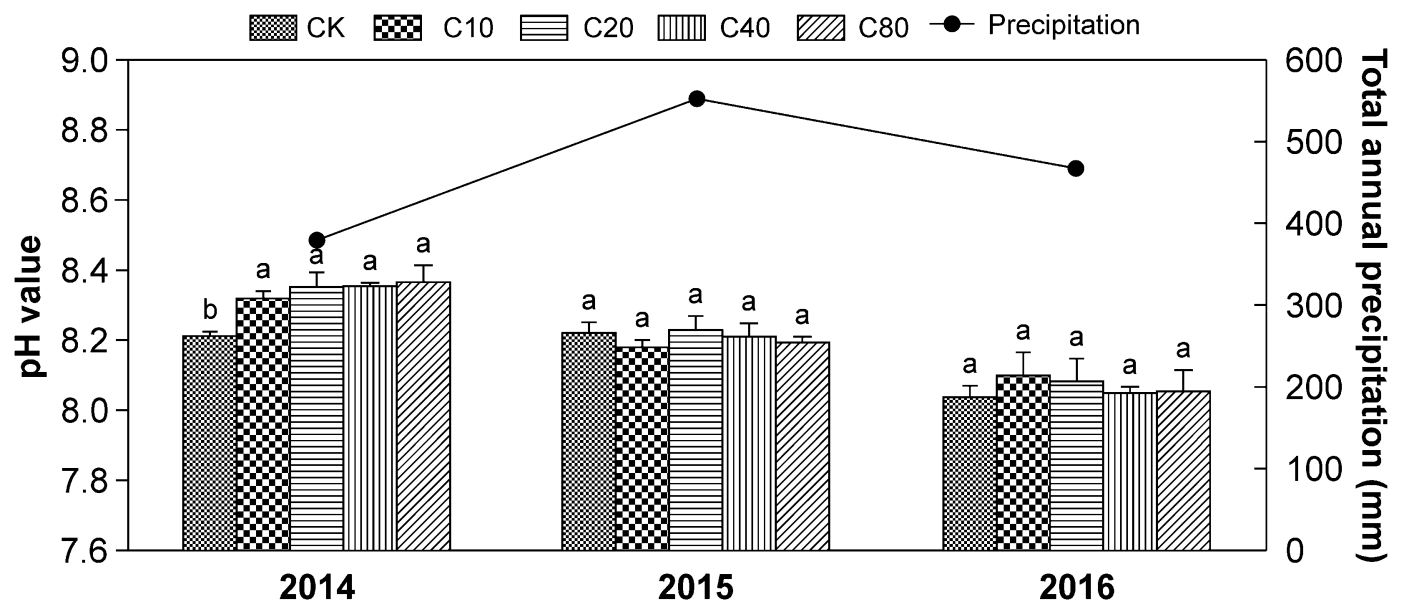

Fig. 7. Effects of different application amounts of biochar and rainfall on meadow soil $\mathrm{pH}$ from 2014 to 2016 
This may have been because the high $\mathrm{pH}$ of the biochar itself affected the soil $\mathrm{pH}$. In 2015 and 2016, the $\mathrm{pH}$ values of the different treatments and $\mathrm{CK}$ did not show any significant differences, and the $\mathrm{pH}$ values in these two years were lower than the $\mathrm{pH}$ in 2014. This may have been because there was greater precipitation $(551.4 \mathrm{~mm})$ in 2015 , and the application of biochar increased soil porosity, which would increase soil permeability in the plow layer, and remove some salts, thereby decreasing the $\mathrm{pH}$. Another cause may have been the highly porous structure of biochar and its extremely strong adsorption capability, which adsorbs some salt ions and decreases $\mathrm{pH}$.

\section{Effects of Different Amounts of Biochar on Meadow Soil CEC}

Soil CEC is important for assessing the soil's fertility-preservation capabilities, improving soil quality, and for rational fertilizer application. An increase in soil CEC can enhance nutrient soil retention, increase soil nutrient utilization rates, and improve soil quality. As shown in Fig. 8, the CEC of various treatments in 2014 were significantly greater compared to the $\mathrm{CK}$ and increased as the amount of biochar applied increased. The cation exchange capacity was greatest under the C80 treatment, $18.3 \%$ greater than that under the CK treatment. In 2015, the different biochar treatments on soil CEC still showed significant promoting effects. The CEC of the C80 treatment was the greatest and was significantly greater than the other biochar treatments. This significant promoting effect was also observed in 2016. Comparisons of the CEC values over the 3 years showed that the CEC slightly decreased as time progressed.

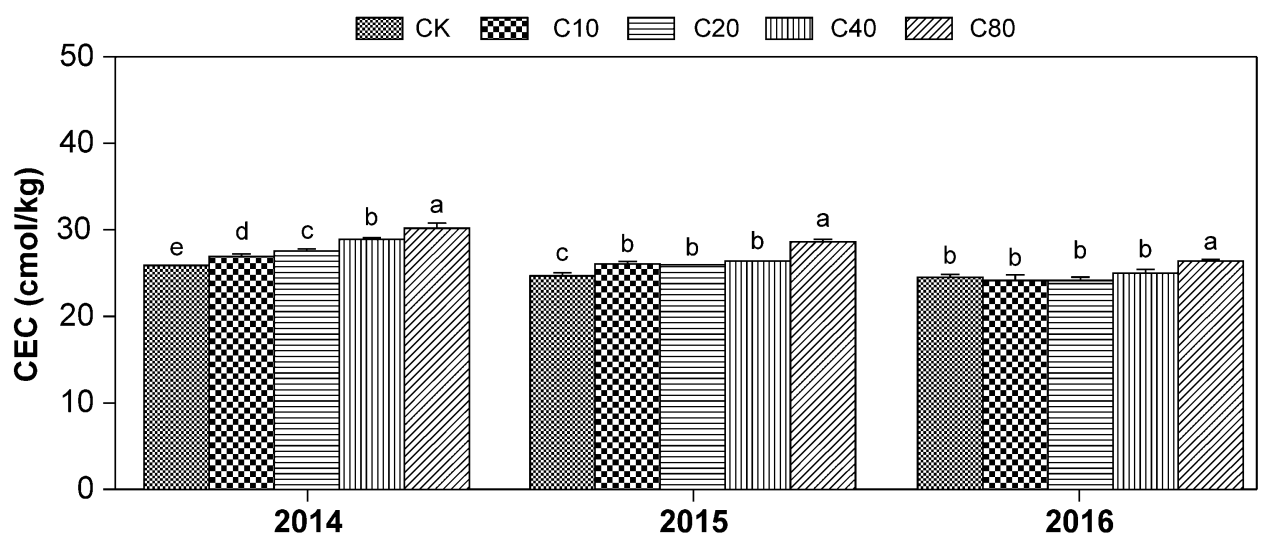

Fig. 8. Effects of different application amounts of biochar on meadow soil CEC from 2014 to 2016

\section{Effects of Different Amounts of Biochar on Maize Yields}

Figure 9 shows the effects of the different amounts of biochar on maize yields. In 2014, the greatest yield was observed with the C40 treatment, followed by the C80 treatment. Compared with the $\mathrm{CK}$ treatment, the two treatments increased the maize yields by $41.2 \%$ and $36.9 \%$, respectively; however, the difference between the two treatments was not significant. The effects of different amounts of biochar on the maize yields in 2015 followed the same trends as those in 2014. In 2016, the maize yields were the greatest in the C80 treatment, which had an increase of $42.1 \%$ compared with that of the CK treatment. This was followed by the C40 treatment, which had an increase of $28.5 \%$ compared with that of the CK treatment. However, the difference between the two treatments was not significant. The $\mathrm{C} 20$ treatment did not show any significant promoting effects on the yield. This showed that high amounts of the biochar (C40 and C80) had continuous promoting effects on the maize yields. 


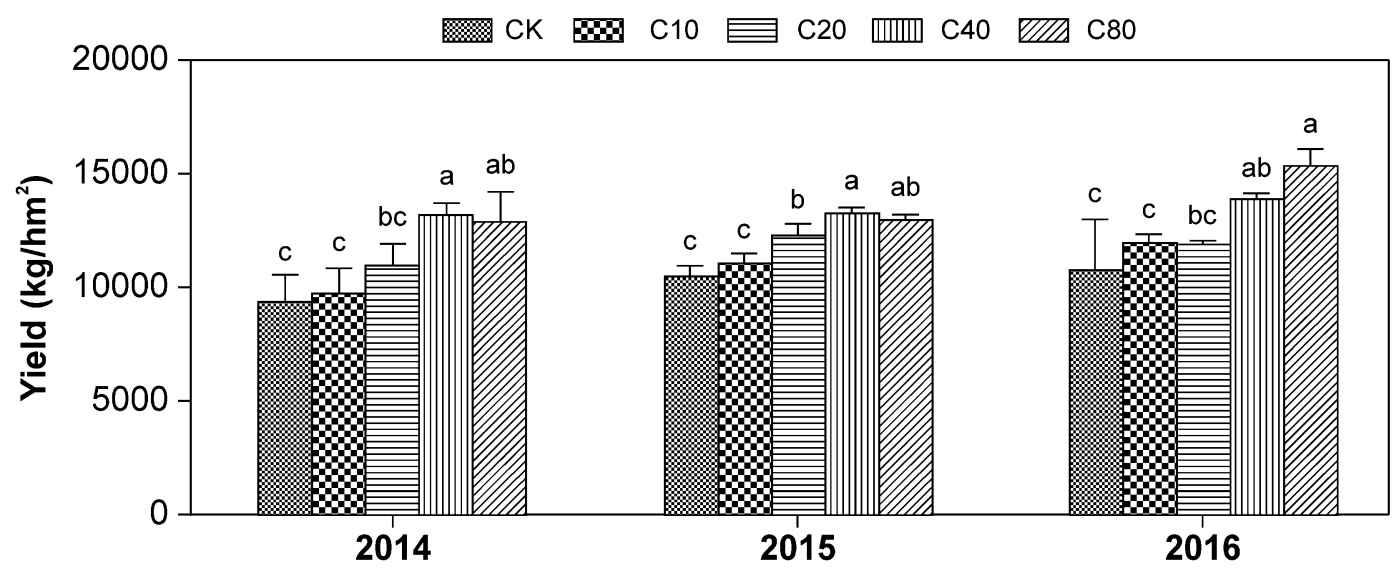

Fig. 9. Effects of different application amounts of biochar on maize yield from 2014 to 2016

\section{Effects of Different Amounts of Biochar on Maize Yield-related Traits}

As shown in Table 5, the different amounts of biochar resulted in significant differences in maize ear length in 2016.

Table 5. Effects of Different Application Amounts of Biochar on Maize Yieldrelated Traits from 2014 to 2016

\begin{tabular}{|c|c|c|c|c|c|c|}
\hline & Year & CK & C10 & C20 & C40 & C80 \\
\hline $\begin{array}{c}\text { Ear Length } \\
(\mathrm{cm})\end{array}$ & 2014 & $17.03 \pm 0.72^{\mathrm{a}}$ & $17.09 \pm 0.45^{\mathrm{a}}$ & $17.59 \pm 0.46^{\mathrm{a}}$ & $18.15 \pm 0.43^{\mathrm{a}}$ & $17.84 \pm 0.87^{\mathrm{a}}$ \\
\cline { 2 - 7 } & 2015 & $18.21 \pm 0.15^{\mathrm{a}}$ & $18.52 \pm 0.66^{\mathrm{a}}$ & $19.03 \pm 0.42^{\mathrm{a}}$ & $18.94 \pm 0.43^{\mathrm{a}}$ & $18.43 \pm 0.84^{\mathrm{a}}$ \\
\cline { 2 - 7 } & 2016 & $16.03 \pm 1.39^{\mathrm{b}}$ & $17.51 \pm 1.12^{\mathrm{ab}}$ & $16.04 \pm 1.02^{\mathrm{b}}$ & $17.61 \pm 0.66^{\mathrm{ab}}$ & $18.17 \pm 0.52^{\mathrm{a}}$ \\
\hline $\begin{array}{c}\text { Barren Ear Tip } \\
\text { (cm) }\end{array}$ & 2014 & $0.98 \pm 0.56^{\mathrm{a}}$ & $0.80 \pm 0.44^{\mathrm{a}}$ & $0.77 \pm 0.20^{\mathrm{a}}$ & $0.43 \pm 0.15^{\mathrm{a}}$ & $0.68 \pm 0.30^{\mathrm{a}}$ \\
\cline { 2 - 7 } & 2015 & $1.22 \pm 0.45^{\mathrm{a}}$ & $0.97 \pm 0.55^{\mathrm{ab}}$ & $0.24 \pm 0.13^{\mathrm{c}}$ & $0.46 \pm 0.11^{\mathrm{bc}}$ & $0.96 \pm 0.32^{\mathrm{ab}}$ \\
\cline { 2 - 7 } & 2016 & $1.85 \pm 0.41^{\mathrm{a}}$ & $1.70 \pm 0.39^{\mathrm{ab}}$ & $1.25 \pm 0.17^{\mathrm{b}}$ & $1.51 \pm 0.18^{\mathrm{ab}}$ & $1.25 \pm 0.12^{\mathrm{b}}$ \\
\hline $\begin{array}{c}\text { Grain Number Row } \\
\text { (grain/row) }\end{array}$ & 2014 & $31.93 \pm 3.25^{\mathrm{ab}}$ & $32.00 \pm 3.27^{\mathrm{ab}}$ & $28.43 \pm 1.33^{\mathrm{b}}$ & $33.80 \pm 4.16^{\mathrm{ab}}$ & $35.13 \pm 1.15^{\mathrm{a}}$ \\
\cline { 2 - 7 } & 2015 & $37.00 \pm 1.31^{\mathrm{b}}$ & $37.80 \pm 1.42^{\mathrm{ab}}$ & $39.93 \pm 1.76^{\mathrm{a}}$ & $39.87 \pm 1.34^{\mathrm{a}}$ & $37.57 \pm 1.33^{\mathrm{ab}}$ \\
\cline { 2 - 7 } & 2016 & $32.33 \pm 1.16^{\mathrm{b}}$ & $34.43 \pm 2.01^{\mathrm{ab}}$ & $33.47 \pm 2.29^{\mathrm{ab}}$ & $35.87 \pm 1.00^{\mathrm{a}}$ & $36.20 \pm 1.73^{\mathrm{a}}$ \\
\hline $\begin{array}{c}100-k e r n e l \\
\text { Weight (g) }\end{array}$ & 2014 & $39.14 \pm 2.15^{\mathrm{b}}$ & $40.29 \pm 1.93^{\mathrm{ab}}$ & $40.21 \pm 0.56^{\mathrm{ab}}$ & $43.31 \pm 0.88^{\mathrm{a}}$ & $42.95 \pm 2.79^{\mathrm{a}}$ \\
\cline { 2 - 7 } & 2015 & $45.48 \pm 0.88^{\mathrm{c}}$ & $46.18 \pm 0.59^{\mathrm{bc}}$ & $47.74 \pm 0.54^{\mathrm{a}}$ & $47.32 \pm 0.41^{\mathrm{a}}$ & $46.72 \pm 0.33^{\mathrm{ab}}$ \\
\cline { 2 - 6 } & 2016 & $40.963 \pm 2.29^{\mathrm{b}}$ & $44.28 \pm 3.79^{\mathrm{ab}}$ & $43.91 \pm 5.88^{\mathrm{ab}}$ & $46.64 \pm 2.04^{\mathrm{ab}}$ & $47.84 \pm 0.99^{\mathrm{a}}$ \\
\hline
\end{tabular}

Note: Different letters after values in the same row indicate that the inter-treatment differences were significant $(p<0.05)$

The C80 treatment resulted in significantly longer ears than the CK treatment, and there were no significant differences between the other treatments. Biochar applications 
alleviated the barren ear tip characteristic to varying degrees and resulted in variable increases in grain number per row. In 2014, the C40 and C80 treatments significantly increased the 100-kernel weight. In 2015, the C20, C40, and C80 treatments significantly increased the 100-kernel weight. In 2016, the C80 treatment continued to have significant promoting effects on the 100-kernel weight. This showed that the high application rates of biochar were beneficial to maize kernel accumulation.

\section{Correlation Between Maize Kernel Yield and Various Parameters}

As shown in Table 6, the maize kernel yields were significantly or highly significantly correlated with the soil organic carbon, total nitrogen, available $\mathrm{K}$, and CEC in 2014, 2015, and 2016. Maize kernel yields were positively correlated, but not significantly so, with the soil available $\mathrm{P}$ content and soil $\mathrm{C} / \mathrm{N}$ in the first two years of biochar application; however, in the third year, the positive correlation was highly significant. The yield was significantly or highly significantly correlated with the ear length, grain number per row, and 100-kernel weight, while it was negatively correlated with barren ear tip.

Table 6. Analysis of the Correlation Between Maize Kernel Yield and Various Parameters from 2014 to 2016

\begin{tabular}{|c|c|c|c|}
\hline \multirow{2}{*}{ Soil Parameter } & \multicolumn{3}{|c|}{ Correlation Coefficient } \\
\cline { 2 - 4 } & 2014 & 2015 & 2016 \\
\hline Organic carbon & $0.821^{* *}$ & $0.567^{\star}$ & $0.867^{* *}$ \\
\hline Total nitrogen & $0.816^{* *}$ & $0.594^{*}$ & $0.804^{* *}$ \\
\hline C/N & 0.401 & 0.510 & $0.822^{* *}$ \\
\hline Available P & 0.464 & 0.418 & $0.826^{* *}$ \\
\hline Available K & $0.836^{* *}$ & $0.665^{* *}$ & $0.606^{*}$ \\
\hline CEC & $0.695^{* *}$ & $0.690^{* *}$ & $0.657^{* *}$ \\
\hline Ear length & $0.801^{* *}$ & 0.359 & $0.700^{* *}$ \\
\hline Barren ear tip & -0.270 & $-0.557^{*}$ & -0.208 \\
\hline Grain number per \\
row & 0.317 & 0.446 & $0.703^{* *}$ \\
\hline 100 -kernel weight & $0.890^{* *}$ & $0.614^{*}$ & $0.659^{* *}$ \\
\hline
\end{tabular}

Note: ${ }^{*}=p<0.05 ;{ }^{* *}=p<0.01$

\section{Effects of Different Amounts of Biochar on Meadow Soil Traits}

The results showed that the biomass was rich in organic carbon and could increase the soil organic carbon content. As the amount of biochar applied was increased, the soil organic carbon content was also increased. Over the period of three years, high levels of soil organic carbon content were maintained, although a slight decrease was observed as time progressed. These changes probably occurred because biochar has a high carbon content, a complex aromatic structure, and high levels of carboxylic esters. This inert carbon pool has high chemical and microbiological stability in the soil environment. Over time the stability of soil organic carbon has been changing, the active organic carbon mineralized quickly, and the stable organic carbon slowly degraded over a relatively long time. Consequently, the soil organic carbon content decreases every year (Kimetu and Lehmann 2010; He et al. 2017).

A single application of the biochar could promote the total nitrogen content in the soils for 3 years, and the amount of biochar applied was directly proportional to the total nitrogen content in the soil. In addition to the nitrogen contributed by the biochar itself, 
another possible reason for this result may have been that the biochar application increased the soil organic matter content; $\mathrm{C} / \mathrm{N}$ is beneficial for increasing soil microbial activity, which promotes the mineralization of soil organic matter, thereby releasing more nitrogen (Shang et al. 2015). However, soil total nitrogen gradually decreased as time progressed. In addition to natural factors, a probable explanation may have been the gradual decrease in soil organic matter, resulting in changes to other soil components.

Phosphorus is an essential macronutrient for plant growth. The biochar application increased the available $\mathrm{P}$ content in the soils for three years, compared with the $\mathrm{CK}$ treatment; the available P content of $\mathrm{C} 10, \mathrm{C} 20, \mathrm{C} 40$, and $\mathrm{C} 80$ treatments increased by 16.6, $22.2,35.2$, and $37.2 \%$, respectively. The soil at the study site was meadow soil, which is rich in total phosphorous but low in available $\mathrm{P}$. The biochar application increased soil phosphorus availability. Chintala et al. (2013) found that biochar itself has some ability to adsorb and desorb phosphorus and will affect soil adsorption and desorption of phosphorus after application. DeLuca et al. (2015) found that, when biochar with high $\mathrm{pH}$ and CEC is applied to soil, phosphorus adsorption by oxides of iron, aluminum, and calcium are blocked, thereby increasing phosphorus activity. Another study showed that the rich pore structure and specific surface area of biochar provided a good living environment for microorganisms, and the rapid growth of microorganisms can promote the availability transformation of soil phosphorus. Biochar changes the physiochemical morphological characteristics of phosphorus in soil, which are beneficial for improving the effectiveness of phosphorus.

Biochar has high potassium availability and can increase soil available $\mathrm{K}$ and potassium absorbed by crops when biochar is applied to the soil (Lehmann et al. 2003). In this study, soil available $\mathrm{K}$ content was directly proportional to the amount of biochar applied. Compared with the CK treatment, the available K content in the C10, C20, C40, and C80 treatments increased by 18.0, 24.7, 49.2, and 67.3\%, respectively. The conclusion was consistent with that drawn by Zeng et al. (2013). Application of 40 and $80 \mathrm{t} / \mathrm{ha}$ of biochar yielded sufficient soil available $\mathrm{K}$ for the three continuous years. Biochar application can increase soil available $\mathrm{K}$ content by directly providing available $\mathrm{K}$ and indirectly reducing the leaching and loss of potassium from soil. This study found that the soil $\mathrm{pH}$ increased in the first year and decreased in the last two years. One reason may be precipitation. Another may be the adsorption of a large number of salt ions by the strong macroporous structures of biochar. Chintala et al. (2013) studied the addition of biochar produced from the pyrolysis of maize straws, switchgrass, and pine wood residues. Their results showed that $\mathrm{pH}$ is less affected when these three types of biochar are added to basic soils. This was further corroborated by this study's results.

Cation exchange capacity reflects the ability of soil to absorb, retain, and exchange cations and is an important factor for improving soil (Dai 2017). The biochar application significantly increased soil CEC, which increased as the amount of biochar applied increased. Application of $80 \mathrm{t} / \mathrm{ha}$ of biochar increased soil CEC consistently for three years. Several previous studies have reported that biochar application can increase soil CEC, regardless of whether it is added to acidic or basic soils (Hossain et al. 2010; Laird et al. 2010). Liang et al. (2006) found that the soil CEC increases as the level of oxidation on the surface of the organic matter in soil or surface cation exchange points on the soil surfaces increase. Glaser et al. (2001) found that the oxidation of aromatic carbons and the formation of carboxyl groups may be the reason for increased CEC. This study also found that the soil cation exchange capacity decreased slightly over the years. This may be due to rain water caused by the loss of carboxyl hydrophilic compounds, which can bind to the 
metal ions and thus, reduce the cation exchange capacity (Uchimiya et al. 2011). Increased soil CEC enhanced the soil retention of nutrients, increased soil nutrient utilization rates, and improved soil quality, which are important for the sustainable utilization of soils.

\section{Effects of Biochar on Maize Yield}

The biochar application increased maize yields. In addition, maize yields generally increased as the amount of biochar applied increased. This was consistent with the results of Uzoma et al. (2011), who studied the effects of biochar application to sandy soils with maize. They found that biochar application increased maize yields, and yields were significantly increased as the proportion of biochar added was increased. Similar conclusions were made by Jiang et al. (2015) and Liu et al. (2015).

This study also found that a single biochar application of 40 or 80 t/ha to meadow soil stably increased maize yields for three continuous years. This was due to the synergistic mutual promotion between biochar and soils. In weakly basic meadow soils, biochar uses its loose and porous characteristics and great specific surface area to adsorb salt ions from the soil, resulting in a yearly decrease in soil $\mathrm{pH}$ (Cox et al. 2001). The application of biochar results in the change of the soil structure, and its inherent characteristics and structure improve soil organic matter content and soil water and fertilizer retention capacity (Yin et al. 2018). In addition, the adsorption of soil enzyme reaction substrate promotes the enzymatic reaction, enhances the soil enzyme activity, and promotes the effective transformation of soil nitrogen, phosphorus, and potassium. (Czimczik and Masiello 2007; Lehmann and Joseph 2009). Biochar can also promote the growth of specific microorganisms and change the microbial community structure, abundance, and activity (Steinbeiss et al. 2009). Moreover, the proliferation of large numbers of beneficial microorganisms not only promotes the conversion of available nutrients in soil but also continually degrades biochar. This beneficial cycle caused improvements to soil quality within three years of the application of the appropriate amounts of biochar and increased crop yields. Additionally, the sustained beneficial effects remain as time progresses. This research is a reference method for improving soil nutrient management and agricultural resource utilization rates in farmlands, increasing farmland productivity, effectively reducing the costs of agricultural production, and supporting the protection of the natural environment.

\section{CONCLUSIONS}

1. Single biochar applications promoted organic carbon, total nitrogen, available $\mathrm{K}$ in soil, and the cation exchange capacity (CEC) for three continuous years in meadow soils, and their levels were proportional to the amount of biochar applied. As time progressed, the soil organic carbon, total nitrogen, available K, and CEC decreased yearly. The biochar stimulated the availability of soil phosphorus in meadow soil and stably increased the available $\mathrm{P}$ content in soil for three years.

2. A single application of more than $40 \mathrm{t} / \mathrm{ha}$ of biochar to semi-arid meadow soil in the western Heilongjiang province of China stably increased maize yields for three years. 


\section{ACKNOWLEDGMENTS}

The authors are grateful for the support of the Heilongjiang Bayi Agricultural University Three Horizontal Three Vertical Support Plan (ZRCPY201803), the Centrally Guided Local Science and Technology Development (ZY16A06), the Agriculture and Reclamation Bureau Project (HNK135-02-05), the Ministry of Agriculture Northeast China Crop Cultivation Science Observation and Experimental Station Open Project (2017-4), the Heilongjiang Bayi Agricultural University Student Innovation Training Project (XC2018006), and the National Thirteenth Five-year Plan key research and development project "Biochar fertilizer and microbial fertilizer research and development" (2017YFD0200803).

\section{REFERENCES CITED}

Akhtar, S. S., Andersen, M. N., and Liu, F. (2015). "Residual effects of biochar on improving growth, physiology and yield of wheat under salt stress," Agr. Water Manage. 158, 61-68. DOI: 10.1016/j.agwat.2015.04.010

Bao, S. D. (2000). Soil Analysis, China Agriculture Press, Beijing, China.

Bruun, E. W., Petersen, C. T., Hansen, E., Holm, J. K., and Hauggaard-Nielsen, H. (2014). "Biochar amendment to coarse sandy subsoil improves root growth and increases water retention," Soil Use Manage. 30(1), 109-118. DOI: $10.1111 /$ sum. 12102

Chen, W. -F. A. (2012). "Combined biomass pellet carbonization furnace and a carbon production method thereof," China Patent No. CN 102092709.

Chintala, R., Schumacher, T. E., McDonald, L. M., Clay, D. E., Malo, D. D., Papiernik, S. K., Clay, S. A., and Julson, J. L. (2013). "Phosphorus sorption and availability from biochars and soil/biochar mixtures," Clean - Soil, Air, Water 42(5), 626-634. DOI: $10.1002 /$ clen.201300089

Cox, D., Bezdicek, D., and Fauci, M. (2001). "Effects of compost, coal ash, and straw amendments on restoring the quality of eroded Palouse soil," Biol. Fert. Soils 33(5), 365-372. DOI: $10.1007 / \mathrm{s} 003740000335$

Czimczik, C. I., and Masiello, C. A. (2007). "Controls on black carbon storage in soils," Global Biogeochem. Cy. 21(3), GB3005. DOI: 10.1029/2006GB002798

Dai, L. (2017). Preparation of Biochar and Effects on Modification of Albic Soil and Greenhouse Gas Emissions, Ph.D. Dissertation, Northeast Agricultural University, Harbin, China. (In Chinese)

DeLuca, T. H., MacKenzie, M. D., and Gundale, M. J. (2015). "Biochar effects on soil nutrient transformations," in: Biochar for Environmental Management: Science and Technology, $2^{\text {nd }}$ Ed., J. Lehmann and S. Joseph (eds.), Routledge, London, UK.

Glaser, B., Haumaier, L., Guggenberger, G., and Zech, W. (2001). "The 'terra preta' phenomenon: A model for sustainable agriculture in the humid tropics," Naturwissenschaften 88(1), 37-41. DOI: 10.1007/s001140000193

Glaser, B., Lehmann, J., and Zech, W. (2002). "Ameliorating physical and chemical properties of highly weathered soils in the tropics with charcoal - A review," Biol. Fert. Soils 35(4), 219-230. DOI: 10.1007/s00374-002-0466-4

He, T., Meng, J., Chen, W., Liu, Z., Cao, T., Cheng, X., Huang, Y., and Yang, X. (2017). "Effects of biochar on cadmium accumulation in rice and cadmium fractions of soil: 
A three-year pot experiment," BioResources 12(1), 622-642. DOI:

10.15376/biores.12.1.622-642

Hong, C. (2018). The Effects of the Soil Modifiers on the Bioavailability of Phosphorus and the Physical Properties in Acid Soils, Master's Thesis, Zhejiang University, Zhejiang, China. (In Chinese)

Hossain, M. K., Strezov, V., Chan, K. Y., and Nelson, P. F. (2010). "Agronomic properties of wastewater sludge biochar and bioavailability of metals in production of cherry tomato (Lycopersicon esculentum)," Chemosphere 78(9), 1167-1171. DOI: 10.1016/j.chemosphere.2010.01.009

Jiang, J., Wang, H.-W., Liu, G.-L., Feng, Y., Wu, Z.-X., Wang, J.-J., Liu, H.-L., Bu, Y.F., and Li, F.-H. (2015). "Effect of biochar on root characteristics and yield in maize," J. Maize Sci. 23(4), 62-66. DOI: 10.13597/j.cnki.maize.science.20150412

Jin, L., Wei, D., Guo, W.-Y., Xu, M., Zhang, L., Li, Y.-D., Chang, B.-C., Gao, Z.-C., Gu, X.-J., and Zhao, S.-D. (2015). "The effects of chemical fertilizer, combined application of chemical fertilizer and biochar application rates on soil physical condition, soybean morphological index and yield," China Soils Fert. 2015(2), 29-32. DOI: $10.11838 /$ sfsc. 20150206

Kimetu, J. M., and Lehmann, J. (2010). "Stability and stabilisation of biochar and green manure in soil with different organic carbon contents," Aust. J. Soil Res. 48(7), 577585. DOI: $10.1071 /$ SR10036

Laird, D. A., Fleming, P., Davis, D. D., Horton, R., Wang, B., and Karlen, D. L. (2010). "Impact of biochar amendments on the quality of a typical Midwestern agricultural soil," Geoderma 158(3-4), 443-449. DOI: 10.1016/j.geoderma.2010.05.013

Lehmann, J., Da Silva, Jr., J. P., Steiner, C., Nehls, T., Zech, W., and Glaser, B. (2003). "Nutrient availability and leaching in an archaeological Anthrosol and a Ferralsol of the Central Amazon basin: Fertilizer, manure and charcoal amendments," Plant Soil 249(2), 343-357. DOI: 10.1023/A:1022833116184

Lehmann, J., Gaunt, J., and Rondon, M. (2006). "Bio-char sequestration in terrestrial ecosystems - A review," Mitig. Adapt. Strat. Gl. 11(2), 403-427. DOI: 10.1007/s11027-005-9006-5

Lehmann, J., and Joseph, S. (2009). Biochar for Environmental Management: Science and Technology, Earthscan, London, UK. DOI: 10.4324/9781849770552

Lehmann, J., Rillig, M. C., Thies, J., Masiello, C. A., Hockaday, W. C., and Crowley, D. (2011). "Biochar effects on soil biota - A review," Soil Biol. Biochem. 43(9), 18121836. DOI: 10.1016/j.soilbio.2011.04.022

Liang, B., Lehmann, J., Solomon, D., Kinyangi, J., Grossman, J., O’Neill, B., Skjemstad, J. O., Thies, J., Luizão, F. J., Petersen, J., et al. (2006). "Black carbon increases cation exchange capacity in soils," Soil Sci. Soc. Am. J. 70(5), 1719-1730. DOI: 10.2136/sssaj2005.0383

Liang, F., Li, G.-T., Lin, Q.-M., and Zhao, X.-R. (2014). "Crop yield and soil properties in the first 3 years after biochar application to a calcareous soil," J. Integr. Agr. 13(3), 525-532. DOI: 10.1016/S2095-3119(13)60708-X

Lin, Q. Y. (2018). Biochar Simulate Aging and Its Potential Analysis on Improvement of the Acid Red Soil, Master's Thesis, Huazhong Agricultural University, Wuhan, China. (In Chinese)

Liu, Y., Khan, M. J., Jin, H., Bai, X., Xie, Y., Zhao, X., Wang, S., and Wang, C. (2015). "Effects of successive application of crop-straw biochar on crop yield and soil properties in cambosols," Acta Pedologica Sinica 52(4), 849-858. DOI: 


\section{$10.11766 /$ trxb201412020611}

Mohammadi, K. (2012). "Phosphorus solubilizing bacteria: Occurrence, mechanisms and their role in crop production," Resources and Environment 2(1), 80-85.

Novak, J. M., Lima, I., Xing, B., Gaskin, J. W., Steiner, C., Das, K. C., Ahmedna, M., Rehrah, D., Watts, D. W., Busscher, W. J., et al. (2009). "Characterization of designer biochar produced at different temperatures and their effects on a loamy sand," Ann. Env. Sci. 3, 195-206.

Oguntunde, P. G., Abiodun, B. J., Ajayi, A. E., and Van de Giesen, N. (2008). "Effects of charcoal production on soil physical properties in Ghana," J. Plant Nutr. Soil Sc. 171(4), 591-596. DOI: 10.1002/jpln.200625185

Rehrah, D., Bansode, R. R., Hassan, O., and Ahmedna, M. (2016). "Physico-chemical characterization of biochars from solid municipal waste for use in soil amendment," J. Anal. Appl. Pyrol. 118, 42-53. DOI: 10.1016/j.jaap.2015.12.022

Shang, J., Geng, Z.-C., Chen, X.-X., Zhao, J., Geng, R., and Wang, S. (2015). "Effects of biochar on soil organic carbon and nitrogen and their fractions in a rainfed farmland," Journal of Agro-Environment Science 34(3), 509-517. DOI:

10.11654/jaes.2015.03.013

Steinbeiss, S., Gleixner, G., and Antonietti, M. (2009). "Effect of biochar amendment on soil carbon balance and soil microbial activity," Soil Biol. Biochem. 41(6), 13011310. DOI: 10.1016/j.soilbio.2009.03.016

Uchimiya, M., Wartelle, L. H., Klasson, K. T., Fortier, C. A., Lima, I. M. (2011). "Influence of pyrolysis temperature on biochar property and function as a heavy metal sorbent in soil," J. Agric. Food. Chem. 59(6), 2501-2510. DOI: $10.1021 / \mathrm{jf104206 \textrm {c }}$

Uzoma, K. C., Inoue, M., Andry, H., Fujimaki, H., Zahoor, A., and Nishihara, E. (2011). "Effect of cow manure biochar on maize productivity under sandy soil condition," Soil Use Manage. 27(2), 205-212. DOI: 10.1111/j.1475-2743.2011.00340.x

Yin, D. -W., Meng, J., Shi, G.-Z., Cao, T., Chen, Z., Zhou, J., Zheng, G.-P., and Chen, W.-F. (2018). "Biochar as tool to improve physicochemical properties of Chinese albic soils," J. Biobased Mater. Bioenergy, 12(1), 102-108. DOI: 10.1166/jbmb.2018.1735

Yin, Y.-F., He, X.-H., Gao, R., Ma, H.-L., and Yang, Y.-S. (2014). "Effects of rice straw and its biochar addition on soil labile carbon and soil organic carbon," J. Integr. Agr. 13(3), 491-498. DOI: 10.1016/S2095-3119(13)60704-2

Zeng, A., Liao, Y.-C., Zhang, J.-L., Sui, Y.-W., and Wen, X.-X. (2013). "Effects of biochar on soil moisture, organic carbon and available nutrient contents in manual loessial soils," Journal of Agro-Environment Science 32(5), 1009-1015.

Zhang, H., Huang, Y., Liu, G., Xu, Y., Liu, J., Bei, Q., Lin, X., Zhu, J., and Xie, Z. (2010). "Effects of biochar on corn growth, nutrient uptake and soil chemical properties in seeding stage," Journal of Eco-Environment, Ecology and Environmental Sciences 2010(11), 1-5. DOI: 10.16258/j.cnki.1674-5906.2010.11.010

Article submitted: January 28, 2019; Peer review completed: March 24, 2019; Revised version received: April 6, 2019; Accepted: April 7, 2019; Published: April 9, 2019.

DOI: 10.15376/biores.14.2.4194-4209 